\title{
Theology in multi-faith Religious Education: A taboo to be broken?
}

Rob Freathy ${ }^{\mathrm{a} 1}$ and Anna Davis ${ }^{\mathrm{a}}$

a. Graduate School of Education, University of Exeter, Exeter, UK.

\begin{abstract}
This article discusses the place of 'theology' in multi-faith Religious Education (RE) in English schools without a religious affiliation, highlighting reasons for its sometimes taboo-status, particularly since the emergence of Ninian Smart's phenomenological approach to Religious Studies in the late 1960s. The article explores a diversity of definitions of theology within specific professional and ecclesiastical discourses, and recasts recent debates by focusing not on whether theology and theological inquiry should contribute to so-called 'non-confessional' RE, but on how different forms of theology and theological inquiry might do so legitimately. In the process, the article challenges binary oppositions that have traditionally distinguished the disciplines of Theology from Religious Studies, and argues in favour of the application of various forms of theology and theological inquiry within a critical, dialogic and inquiry-led approach to multi-faith RE. What this might mean in practice is discussed with regard to three concepts: positionality, empathy and critique. Ultimately, multi-faith RE is characterised as occupying a liminal space betwixt and between disciplinary, interpretative and methodological perspectives involved in the study of religion(s) and worldview(s).
\end{abstract}

\section{Keywords}

Theology, Theological Inquiry, Religious Education (RE), Pedagogy

\section{Funding}

The work was supported by the Westhill Endowment Tust and Bible Society (England and Wales) as part of 'The Art of Narrative Theology in Religious Education: Phase Four' project.

\footnotetext{
${ }^{1}$ Corresponding author. Email: r.j.k.freathy@exeter.ac.uk
} 


\section{Theology in multi-faith Religious Education: A taboo to be broken?}

This article is about theology, its definition(s) and its place in multi-faith Religious Education (RE) in English schools without a religious affiliation. Theology is a polysemic word having various meanings even within common discourse. At times, 'theology' (often in the lower case) is used as a noun referring to a theistic worldview and within that the (in)formal attempts of believers in God to organise, communicate, contemplate and/or justify their ideas, sometimes accompanied by the prefix 'popular' or 'lay' (Schweitzer 2014). In this sense, it does not normally apply to non-theistic religions and worldviews, or the attempts of 'outsiders' to reach an understanding of such. 'Theology' can also be used as a proper noun (often in the upper case), such as when referring to an academic discipline or field within higher education. In this sense, Theology may require the pre-requisite of theistic faith, for example, in the (vocational) setting of a theological college or seminary. Alternatively, it may occur in secular institutional settings, where normally neither staff nor students are required (or expected) to hold theistic beliefs, even though such beliefs are a focus of study. Within these different contexts, at the extremes, academic Theology can refer to (i) a single, well-defined discipline, primarily orientated around 'systematic theology', which has to do with a core body of knowledge and the traditions involved in engaging with and applying it (e.g. doctrines and liturgy), or (ii) a multior inter-disciplinary field of inquiry, encompassing theories and concepts, interpretations and perspectives, and/or methodologies and methods shared with other disciplines. Here 'systematic theology' is one component among others drawn from across the humanities (e.g. history, languages and literature) and social sciences (e.g. psychology, sociology and anthropology). Theology can also be used (prefixed by an adjective) in diverse ways to refer to the theologies of different Christian denominations (Catholic, Protestant, Free Church, etc.), to multiple theological traditions (neoOrthodox, Feminist, Post-Colonial, Black, Feminist, Queer, etc.), and/or to the theologies of nonChristian theistic faiths (Jewish, Islamic, Sikh, etc.). In addition, theology can be used as a verb in the form of 'theologise' meaning to 'do', 'enact' or 'implement' any of the above forms of theology. This variety of definitions highlights that theology can refer to the 'content(s)' and/or 'method(s)' of theological thought, inquiry and communication. Furthermore, the practice of 'theological inquiry' can itself be subject to examination and critique, theologically or otherwise.

The place of theology in multi-faith RE has been a disputed matter (Cush 1999) and continues to be (Roebben 2016), especially in the context of English schools without a religious affiliation, which are not permitted by law to provide RE by means of any catechism or formulary distinctive of a particular religious denomination (although such may be studied). Sometimes these disputes are about the balance between theological and other approaches to the study of religion(s) in RE (Bloom 2018; The Church of England 2018). At other times they are about whether theology should have a place at all (Brine 2016a; 2016b; 2017; 2018; Howard 2016). Some have argued, as did Smart (1983), that theology can only feature as part of so-called 'confessional' RE in schools with a religious affiliation, and that schools without a religious affiliation should instead adopt a 'non-confessional' Religious Studies approach (Netto 1989). Others have suggested that theology can also contribute to multi-faith RE in schools without a religious affiliation (Astley and Francis 1996; Reed et al. 2013), although such attempts have often failed to conceptualise clearly and coherently what is meant by 'theology' and 'theologising' within this particular context (Copley 2001; 2005). This article recasts these debates, not by focusing on whether theology and theological inquiry should contribute to so-called 'non-confessional' multi-faith RE, but on how they might do so legitimately, bearing in mind that neither are singular, homogeneous and monolithic, as demonstrated by the diversity of definitions 
noted above. In so doing, the article will examine existing ideas within specific professional and ecclesiastical discourses, and argue in favour of the application of various forms of theology and theological inquiry as part of a critical, dialogic and inquiry-led approach to multi-faith RE in schools without a religious affiliation. If there has been a prohibition on the part of some stake-holders surrounding the application of theology within this particular educational context, then this article seeks to break the taboo.

\section{Theology and RE}

In England, the relationship between RE and Christian theology (usually in the form of biblicallyorientated classroom teaching, involving some study of church history) changed most significantly from the late 1960s. At this time, as Rob Freathy and Stephen Parker have argued:

the subject was beginning to take account of 'the increasing secularisation and pluralism of British society' (Jackson 1990, 107). For example, the Inner London Education Authority's Agreed Syllabus, Learning for Life (1968), was the product of a conference including 'representatives of the Jewish and Muslim communities', and discussed, amongst other things, the problems of teaching non-Christian religions and teaching secular beliefs from a Christian point of view (Hull 1984, 87-88). Such developments occurred against a backdrop which saw the establishment of the departments of Religious Studies (as opposed to Theology) in the universities of Lancaster and Newcastle-upon-Tyne in 1967, and the Shap Working Party on World Religions in Education in 1969. (Freathy and Parker 2015, 9)

Amongst these and other factors (Bates 1994; 1996; Doney 2015a; 2015b; Parker and Freathy 2012), theoretical developments within RE were influenced by the introduction of Ninian Smart's 'phenomenological' approach to the study of religion and the pedagogical discussions which followed subsequently (Copley 2008; Cush 1999).

\subsection{The marginalisation of theology}

Working Paper 36 (Schools Council 1971) has become emblematic of the impact of Smart's phenomenological approach (e.g. Smart 1968) upon RE theory in England. It was 'an attempt to put aside prejudice and preconceptions [and] to empathise with the believer's point of view' (Cush 1999, 138). For Smart, the study of religion needed to be set free from the truth assumptions made by the discipline of 'Theology'; matters of faith should be approached from a position of value-neutrality as embodied in the notion of the phenomenological epochē (Smart 1973). Whereas Theology, according to Smart, requires commitment to certain beliefs and expresses a particular worldview, Religious Studies strives for disinterested impartiality towards the object(s) of study. Religious Studies should, argued Smart, be interreligious and cross-cultural, examining and comparing multiple faith traditions, and benefit from the application of numerous disciplines, including psychology, anthropology, sociology and linguistics (Smart 1983). Smart's phenomenological approach aimed to 'show that understanding religion, including ideology, is a necessary and illuminating part of the human effort to account for the world in which we live' (Copley 2008, 83). Of the advent of this approach, Denise Cush writes: 'it is important to remember the joy and relief with which it was greeted' by RE teachers from the late 1960s 'who were no longer expected to promote confessional beliefs amongst their reluctant pupils' (1999, 138). Dismissed by Working Paper 36 as 'intellectual and cultic indoctrination', so-called 'confessional' approaches to RE came to be viewed as anti-educational, 
with the phenomenological approach instead providing 'an impartial study...appealing to the many teachers who found theologically loaded approaches to RE distasteful' (Jackson 1990, 108).

The phenomenological approach to the study of religion received positive acclaim in the 1970s (e.g. Lealman 1978; Marvell 1976; Sharpe 1975). It seemed to some UK-based commentators as though Religious Studies was set to confine Theology to the religious seminary and leave little room for theological pursuits in RE:

Religious Studies was presenting itself with a fresher, less confessional approach than Theology, whose concerns with church history, compulsory Greek and Hebrew courses, Christian doctrine, Old and New Testament studies etc. were replaced by studies in the psychology, sociology and anthropology of religion and by major emphasis not just on comparative religion but on the study of non-Christian religions in their own right, in degree structures in which the study of Christianity might not be the major component (Copley 2008, 101).

According to Terence Copley $(2008$, 12), following the publication of Working Paper 36, interaction between religious educators and subject-specialist academicians was skewed towards Religious Studies, with Theology often dismissed as 'biased' and 'implicitly Christian'. At the same time, academic theologians showed little interest in the developments taking place within RE. As a result, 'for nearly forty years there has been almost no dialogue between professional religious educators and professional theologians in the UK [...] In its efforts to be perceived as an essentially educational exercise and a not a religious one, RE lost touch with the changes in and insights it might have gained from theology' (Copley 2008, 207). In opposition to this trend, Copley points to the plurality of theologies available (Christian, Jewish, Islamic, Sikh), and the educational desirability of 'getting children to "theologize"' $(2008,12)$.

This article does not seek to assess the validity of these claims empirically. The purpose of referring to selected historical and contemporary debates is to highlight some of the main theoretical issues and to illustrate the potential importance of this article for present professional and ecclesiastical policy and practice. Moreover, in referring to the application of theology in RE as a taboo, we mean for some people, not all. Even if theology has been marginalised, it has not been eradicated and there are many examples of its past and present impact on pedagogical and curricular discourses in RE. Prominent applications include research initiatives, such as The Stapleford Project (Cooling 1994) and the Biblos Project (Copley et al 2005), as well as academic debates concerning the nature and purpose of (religious) education (e.g. Hull 1984; Wright 1993). Other more recent examples are referred to below.

\subsection{Necessary theistic commitment?}

The account above suggests that a primary reason for the marginalisation of theology and theological inquiry in RE was the assumption that theistic belief is a pre-requisite. This assumption lingers in professional discourse today as can be seen, for example, through the publications of Alan Brine: a member of Her Majesty's Inspectorate in the Office for Standards in Education (OFSTED) (200114); OFSTED's National Adviser for RE (2007-14); author of the most recent OFSTED report on RE (2013), and member of the Religious Education Council's Commission on RE (2016-18, www.commissiononre.org.uk). Brine (2016a) argues that students of multi-faith RE in schools 
without a religious affiliation should be introduced to the process of theologising 'as observers but cannot directly participate in it'. It is subject matter to be studied, not a method in which to become engaged. Moreover, whilst a 'diversity of disciplines (history, philosophy, sociology, phenomenology etc.)' can bring depth to the study of religion and belief, he has 'serious doubts whether 'theology' is one of those' (2016b). Citing Stephen Prothero, Brine notes, 'While theologians do religion, religious studies scholars study religion' (Brine 2016b).

Such claims are based upon a particular and restrictive definition of theology - one that characterises the relationship between the personal beliefs of the 'theologian' (whether professional or lay) and the content(s) and method(s) of theological inquiry in a certain way(s). This definition is contingent not necessary. As a simple exemplification, for Cush (1999, 143), there are two basic definitions of disciplinary Theology. One asserts necessary theistic commitment and can be illustrated by Anselm's 'faith seeking understanding', and by Adrian Thatcher's definition of Christian Theology as 'the systematic reflection on God and belief in God, by Christians, for Christians' which makes 'clear differences between Theology and Religious Studies'. The other stresses the critical academic nature of the subject and can be illustrated by Alister McGrath's assertions that Theology has transformed from 'discourse about God' to 'analysis of religious beliefs', and Christian Theology is 'the systematic study of the fundamental ideas of the Christian faith', making no claim as to Christian commitment. Within higher education, Theology can exist as a multi-disciplinary, multimethodological subject, involving learning languages, history, philosophy, etc., of which none require any specific faith commitment (Burton 2013). Theology departments in secular higher education institutions normally do not make faith an admission criterion (Harvard Divinity School 2018), and some theologians are not 'believers' (Schneider 2010). Accordingly, if theistic faith is not necessarily a pre-requisite for theological inquiry (depending on the definition of such), then arguably all students, regardless of their own worldview, can participate equally in learning (i) theological content (e.g. about theistic beliefs and concepts, and what a diverse range of professional/lay and orthodox/heterodox 'theologians' have thought and said about them), and (ii) theological methods (e.g. thinking and researching as theologians, and how such ways of thinking and researching might be critiqued). The study of theistic religions, under whatever disciplinary banner, can involve consideration of 'insider' and 'outsider' perspectives and be open to theistic, atheistic and agnostic scholars.

\section{Making a Difference theologically?}

Among recent calls for the re-inclusion of theology within the RE curriculum has featured the Church of England Archbishops' Council Education Division and National Society's 2014 report Making a Difference, which sets out a vision for the place of theology within RE in Church of England (CofE) schools. Perhaps surprisingly, lead authorship has been attributed to Alan Brine, who was then OFSTED's National Adviser for RE. The report puts forward 'Thinking theologically and the art of theological enquiry' (p. 21, Section 5.1) as one of four priority areas for development, and identifies 'theological enquiry' as the 'distinctive Anglican contribution to the Religious Education debate' ( $\mathrm{p}$. 29, Section 5.35). ${ }^{1}$ In so doing, the report touches upon several definitions of 'theology' outlined above, focusing specifically on a sector of schools with a religious affiliation but, at the same time, attempting to contribute to national debates about RE extending beyond that sector to those without. 


\subsection{Theological inquiry: content}

One definition employed by the report is that of theology as the 'content' for study, including 'key concepts such as incarnation, resurrection [and] atonement', and also learning about 'the diversity of different ways of thinking theologically within the Christian tradition' (p. 28, Section 5.32. Our emphasis). The National Society's recent 'Christianity Project' is also referenced in relation to its promotion of the study of 'the inter-relatedness of [theological concepts] in the Christian story', and of how 'Christian practices and the life of the Church are rooted both in this narrative and these theological concepts' (p. 29, Section 5.36). Similarly, in Rethinking RE: Religious Literacy, Theological Literacy and Theological Enquiry (Chipperton et al. 2016), 'theological literacy' is defined as entailing:

- The foundations of ideas about (e.g.) God (e.g. scripture, tradition, reason, experience);

- The development of the ways in which ideas about (e.g.) God have emerged and changed over time;

- The ways in which ideas about (e.g.) God relate to each other (e.g. how Trinity relates to Incarnation);

- The ways in which ideas about (e.g.) God are applied in everyday living. (p. 4., See also McGrath 2007, 101-2)

In the above examples, theological inquiry pertains to a body of knowledge orientated around core theistic ideas and their application. The emphasis seems to lean towards academic, disciplinary Theology and away from lay/popular theology, and towards the systematic study of concepts and doctrines rather than, for example, languages, exegesis/hermeneutics, history or empirical practical theology. However, it is not totally clear whether the ideas to be learned are those of the theistic faith community itself (e.g. orthodox or heterodox doctrines) and/or derived from the (in-)formal study of the community's ideas (e.g. lay or professional theological inquiry). These could be profoundly different.

Within professional educational discourse, whilst recognising the need for RE to address core foundational beliefs, there is some scepticism about whether or how theological inquiry should do this. For Alan Brine (2018), theology is viewed 'as part of the content of [theistic religions]' and 'as an activity [that] only really takes place inside [them]'. He talks about 'their theology' and the need to understand 'the nature, content, function, history, impact of theology within theistic religions'. Brine (2016a and 2016b) argues that this subject matter is too obscure and esoteric to be a central object of study in RE in schools: the detailed examination of theological doctrines is not something in which many practising Christians regularly engage. He states:

Is the reality of many people's religious identity that it is lived without reference to theological concepts? Privileging those concepts as the 'core' of the religion is in danger of imposing a particular view of orthodoxy on the way we study religious life. As far as the RE curriculum is concerned - we need to remember that for many (most?) people, including many who would self-identify as Christians, theological concepts and processes probably play little or no part in their lives (Brine 2016b). 
However, while not all self-identifying Christians actively engage in systematic academic Theology, there remain other ways in which they do approach, respond to, and engage with notions of the ultimate, transcendent, and/or 'other'. Participation in community, and in the rituals of worship (e.g. liturgical readings, hymn singing, baptism, confirmation and the Eucharist), for example, while less 'academic' in nature and purpose, are nonetheless still behaviours and practices that might be construed as theological, particularly if they lead to, or become the object of, reflection and contemplation. Put simply, the professional Theology of scholars and the popular theology of laypeople may be separated by standards of academic rigour and forms of expression, for example, but united by their orientation to theological subject matter. That members of theistic faith communities do not predominantly engage in what Brine and others consider to be theology, does not mean that the activity, in all its variety, is necessarily unworthy of attention in RE. The spectrum of theological thinking, from the most theologically literate to the least, might be both reflected by, and an object of study within, classroom RE. Christian theology is not the same as Christianity, for example, but it is an aspect of it (in some cases) and relates to it. It is also a scholarly activity engaged in by those who are and are not Christians.

In terms of the broader question of whether 'theology' should be defined by the 'content' of study, it might further be argued that theological inquiry need not be predicated on the basis of uniquely theological subject matter at all. Topics such as 'incarnation', 'the Gospel of John' and 'Christian perspectives on same-sex marriage' could be found in Religious Studies just as much as in Theology: the same content can be shared between these and other disciplines, albeit potentially explored in different ways. It is also possible to produce a theological account of a wide range of seemingly nontheological topics, for example, the environment, work, business, art and sexuality. The sources employed can likewise be shared between diverse disciplines, with historical documents, biblical texts, liturgies and material culture all being utilised by theologians, scholars of religion, historians, philosophers and sociologists, for example, even if for different purposes and disparate ends. So while theology could be defined in relation to distinctive subject content, it need not be so. Theological inquiry within RE can involve the study of a wide range of contrasting ideas, sources, topics and debates.

\subsection{Theological inquiry: method}

The Making a Difference report recognises that there exists a 'diversity of different ways of thinking theologically' (p. 28, Section 5.32). This implies that theological inquiry refers to not only the 'object(s) of study', but also the 'method(s) of study', with no singular approach being advanced. Under this umbrella term one might expect to be grouped a diversity of distinctively theological theories and concepts, interpretations and perspectives, and/or methodologies and methods. In fact, the report simply says, in 'thinking theologically', students move 'beyond the mere collecting of information about religion and belief' to explore the 'crucial inner meanings within the religious material they are studying' (p. 28, Section 5.34). This encouragement of active processes of engagement and exploration, not passive acquisition of transmitted theological facts, is echoed by Gerhard Büttner (2007). He promotes 'theologising with children' - drawing upon Wittgenstein's concept of a 'language game' - to engage students in communication using theological language. Similarly, the Biblos Project $(2004,14)$ adapted Matthew Lipman's (1988) work on 'philosophising' with children to encourage children to 'theologise', that is, to 'think theologically [rather than] become passive students' of Christian theological content. 
Yet what makes these processes of learning distinctively theological? In terms of the broader conceptions of 'theological thinking' or 'theologising', a commitment to deepening understanding of knowledge, and to accessing inner meanings, is found in disciplines other than theology; none of the skills referenced in the Making a Difference report is exclusively theological. Theology can encompass theories and concepts, interpretations and perspectives, and/or methodologies and methods that are shared across the humanities, arts and social sciences. In this regard, theological inquiry may be considered a multi- or inter-disciplinary endeavour, drawing upon history, languages, literature, psychology, sociology, anthropology, etc, to study subject matter that is theological, but it is not a distinctively theological form of inquiry (Brine 2018).

Theology-specific modes of inquiry are nonetheless presumably possible. If specifically theological ideas or doctrines (i.e. about or related to [the concept of] God) are deployed as interpretative frameworks, or theoretical/conceptual lenses, through which other phenomena are understood (particularly distinctively theological phenomena), then it could be argued this is a uniquely theological form of inquiry. However, whilst being possible, such an approach is not necessary, and may at times be undesirable. In the context of multi-faith RE in schools without a religious affiliation, such a conception may be deemed narrowly defined, methodologically constricted and potentially limited in application (i.e. confined to theological interpretations, theorisation and conceptualisation, and theological subject matter). It may also be perceived as being sufficiently close to, or overlapping with, the acceptance or promotion of a theistic worldview as to infringe students' right to freedom of religion and belief. It would certainly be unacceptable for the contents and methods of 'nonconfessional' multi-faith RE as a whole to converge solely on that which was theistic and/or theological. Whilst the law states that schools without a religious affiliation should not provide for RE by means of 'any catechism or formulary which is distinctive of a particular religious denomination' (School Standards and Framework Act, 1998, Schedule 19 Paragraph 3), we would go further. Our fundamental assumption is that RE in such schools should not be provided by means of any singular (religious or non-religious) worldview, philosophy or ideology, or any singular conceptual, theoretical, interpretative or methodological framework. If multi-faith RE in such settings favours a certain epistemological and methodological approach, then it risks 'infringing the liberal principle, and human right, of freedom of belief' because the application of one mode of interpretation might prevent students from accessing knowledge of different points of view and may be incompatible with their sincerely held and reasonable worldviews (Moulin 2009, 153-4).

\subsection{Theological inquiry: one approach among many}

According to the Making a Difference report, RE should involve students in a 'range of different ways of thinking and enquiring' (of which theological inquiry is one), set within the context of a 'repertoire of other approaches towards the promotion of religious literacy ... drawn from, for example, social sciences and philosophy' (p. 28, Section 5.34). In a related discussion, Chipperton et al. (2016) draw a distinction between theological and religious literacy, whilst reflecting on the relationship between them. In contrast to their definition of theological literacy, as noted above, religious literacy involves:

- Asking enquiring questions about religion and belief and making informed responses to them;

- Investigating the nature of religion and belief itself;

- Understanding the impact that religions and belief can have on individuals and society; 
- Understanding the beliefs, practices, values and ways of life of religious and non-religious world views;

- Understanding the diversity of religion and belief in the contemporary world;

- Understanding the use of religious language and the context in which it is expressed. (p. 4)

This is not dissimilar from the definition of religious literacy provided in OFSTED's 2013 report, Religious Education: Realising the Potential (p. 8). Notably, while Chipperton et al.'s definition of 'theological literacy' is focused solely on knowledge of core theological ideas and of their foundations, development, relationships and applications (i.e. subject content knowledge), their descriptions of 'religious literacy' all begin with present participles, referring to continuous learning processes focused on a wider range of religious phenomena. In comparison to 'surface-level' religious literacy, theological literacy is presented as being foundational and 'digging deeper into the concepts at the heart of religion' (p. 6). Writing specifically about the purpose of RE in CofE schools, it is perhaps unsurprising that knowledge of theistic beliefs should be depicted as underpinning all other areas of faith exploration. However, it may unfairly imply that explorations into the non-theological are shallow and superficial.

Although defined differently, for Chipperton et al. (2016), theological and religious literacy are complementary, and both essential to the purpose of RE. However, a false dichotomy is potentially being created. Theology can entail not just ideas/concept-focused content, but a diversity of subject matter and a range of approaches towards its study, traditionally from theistic 'insider' perspectives, but increasingly from atheistic, agnostic and other perspectives (see Hyman 2004, 211). An alternative conceptualisation of the relationship between theological literacy and religious literacy, which not only preserves the richness and diversity of each concept, but also understands the relationships between them as symbiotic rather than hierarchical, would liberate theological inquiry to contribute far more fully and authentically to RE across a wider range of schools.

In the context of UK higher education, the Quality Assurance Agency's Subject Benchmark Statement (2014) presents 'Theology and Religious Studies' as a singular subject area marked by diversity with elements of convergence, and promotes the importance of incorporating a breadth of approaches to the study of religions and beliefs (p. 8). 'Theology and religious studies', it argues, 'may be characterised as a family of methods, subjects and fields of study', providing students with the opportunity to engage in the twofold exercise of:

- exploring the religious thought of one or more traditions so as to understand each in its integrity and diversity, and grasp its integrative role in relation to lifestyles, practices and ethics

- analysing the historical, social, philosophical, cultural and artistic role of religion or belief systems in diverse contexts. (QAA 2014, 10)

This suggests a semantic blurring between 'theology', 'theological inquiry/literacy', 'religious studies', 'religious literacy' and related terms, with little that is fixed and categorical definitionally, and a lot that is fluid and porous. Accordingly, 'theology' within RE could exist as one approach among many, but the boundaries of these approaches would be fuzzy and overlapping. This alone would undermine the unconditional arguments of those for whom the presence of 'theology' per se 
in multi-faith RE in schools without a religious affiliation is a taboo. However, the diversity of definitions of theology and theological inquiry encountered thus far further demonstrates that 'theology' is not a singular, homogeneous and monolithic referent. It would be better to refer, in the plural form, to theologies and theological inquiries with some of these overlapping (more or less) with Religious Studies and other disciplinary approaches. Tautologies often result from attempts to delineate a finite body of theological knowledge, and/or to determine distinctively theological interpretations, methodologies and methods, that can be differentiated, in absolute terms, from the broader heterogeneous repertoire of approaches utilised in the study of religion(s) and worldview(s). For this reason, it may be more constructive to ask not whether theology and theological inquiry should contribute to so-called 'non-confessional' multi-faith RE, but how the different forms of theology and theological inquiry referred to above might do so legitimately.

\section{Making theologies and theological inquiries fit for purpose}

Apparent throughout the Making a Difference report is a clear commitment to a 'theistic interpretation' of theology and theological inquiry. Given the provenance of the report, this is hardly surprising. Yet the CofE is also explicit about its intention for the report to contribute to national debates about RE beyond the 'faith school' sector (p. 29, Section 5.35). As the above discussion shows, such debates have yet to reach fruition. Does this mean that theology and theological inquiry are only appropriate within RE in schools with a religious affiliation? We do not think so, but rather believe they can be revivified elsewhere, with the categorical disciplinary barriers between Theology and Religious Studies being broken down, and provided that certain conditions are fulfilled. These conditions are that any form of theology and theological inquiry deployed must carry no pre-requisite of (theistic) faith commitment on the part of students, and must cohere with the form of critical, dialogic and inquiry-led RE that we otherwise endorse (Freathy et al. 2017). Applications of theologies and theological inquiries that do not fulfil these conditions may be invalid within the context of RE in schools without a religious affiliation.

\subsection{No pre-requisite of faith commitment}

The Making a Difference report claims that all students, regardless of personal belief, should 'engag[e]...with the ideas and beliefs of different faiths', and this can lead to those students 'who bring a personal commitment to the religion being studied...reflecting more deeply on their faith and 'doing theology' for themselves' (p. 28, Section 5.33). The connections made here between personal theistic beliefs, 'thinking theologically', and accessing 'crucial inner meanings' within the material under study (p. 28, Section 5.34), may imply that those who do not 'bring a personal commitment to the religion being studied' cannot do theology for themselves, and that there is a hierarchy of 'knowing', 'understanding' and 'believing', where 'true' understanding can only be accomplished

fully by the 'believer'. Following earlier work by Aylward and Freathy (2008) and Freathy and Aylward (2010), the link between belief and understanding has more recently been explored by Walshe and Teece (2013) in relation to 'religious understanding'. They note, '[f]or some, religious understanding presupposes religious belief as to understand a religious concept is to accommodate it into one's conception of reality' (p. 3). For others, religious understanding is not a matter of belief but an understanding of the 'grammar' of religion, meaning '[i]t is entirely possible ... to understand the claim that is being made (e.g. God is omnipotent), without believing it to be true' (p. 4). The personal beliefs of the 'theologian' (whether theistic, atheistic, agnostic or other) will influence, and be influenced by, their encounter with the content(s) and method(s) of theological inquiry. This may result in different, not better, understanding(s). Even within RE in schools with a religious affiliation, 
such different understanding(s) will be apparent, influenced by which theistic religion is being studied at a given time (that is assuming multi-faith curriculum content), and by the personal faith commitments of the individual students involved, not all of whom will necessarily be members of the relevant faith or uphold orthodox views of the faith.

At the same time, however, it must be remembered that complete neutrality of perspective, such as has been associated with Smart's phenomenological approach, remains impossible. Smart promoted 'value-free descriptions in religion', so as to avoid 'introducing the assumptions and slant of the investigator' $(1973,21 ; 1983,16)$ and, while he admitted that this might not be absolutely possible, he nonetheless maintained that such a position should be an aim (Smart 1998). Accordingly, Religious Studies is often assumed to be free from ideological or philosophical commitments, and Theology is deemed inextricable from theistic faith commitments. Yet the concept of the 'neutral' perspective is in fact an oxymoron: there exists only a plurality of perspectives, faith-based or otherwise. Even within theistic worldviews and within theologies, multiple different and, at times, conflicting perspectives are to be found. Most are (inter-)subjective, reflecting the personal/social stories and experiences that individuals/communities bring to their encounter with the subject matter. As Hyman puts it: "the tradition-specific starting point or "worldview" of liberal modernity is of the same order (i.e., it is another specific tradition) as the particular religious "worldviews" from which the social scientific methodology of religious studies is trying to maintain some form of "detachment" (2004, 199). Gavin D'Costa concurs: 'No non-tradition-specific approach can exist, and such an apparently neutral disembodied location is in fact the tradition-specific starting point of liberal modernity' (2000, 19). Furthermore, Smart's apparent rejection of non-neutral perspectives as necessarily biased and unfair would seem to be without foundation. As Gavin Hyman writes: 'I can be openly situated within my worldview or tradition and be critical of Smart's position on the basis of that worldview without compromising the accuracy and empathy with which I convey Smart's thought' $(2004,200)$.

Both the disciplines of Theology and Religious Studies, then, necessarily involve engaging with subject matter from the position of particular perspectives and/or worldviews. When applied in multifaith RE in schools without a religious affiliation, both should do so openly, deliberately eschewing false notions of objectivity and neutrality in favour of recognising (inter-)subjectivity and traditionspecific reasoning (whether those traditions are worldviews, interpretative frameworks, theoretical/conceptual lenses and/or methodologies). Both should also intentionally expose, reflect upon and critique the assumptions, beliefs and ideologies that are integral to their workings and manifested by students, teachers and curriculum resources. Theology, and also theologicallyinformed Religious Studies, argues Hyman, should 'give rise to a more vibrant and vigorous religious engagement than was allowed for by the insipid and ostensibly neutral tradition of liberal modernity [which, he argues, underpins “pure” Religious Studies]' (2004, 215-7). Theology, Hyman claims, is more aware of its positionality, and therefore the positionality of others, than has traditionally been the case with Religious Studies. For him, Theology enables engagement with the concept of 'perspective' itself - the notion that we all have unique vantage points on the world, and that these influence the ways in which we engage with subject matter, and with each other. A value of theologies and theological inquiries within multi-faith RE in schools without a religious affiliation might be therefore that they provide a means by which students are exposed to the beliefs of others, articulated as such, and given an opportunity to reflect upon their own positionality in relation to these beliefs. This is profoundly different from a conceptualisation of theology and theological inquiry, and of their application within RE, which requires or promotes (as opposed to merely permits) personal 
commitment by participants to a specific theistic faith tradition (or indeed to any particular worldview or perspective).

\subsection{Consistent with critical, dialogic and inquiry-led RE}

We also believe that theologies and theological inquiries (along with any other disciplinary, interpretative and methodological approach) can only be applied appropriately if this application is consistent with the critical, dialogic and inquiry-led vision for RE in schools without a religious affiliation that we have promoted previously (Freathy, R. et al. 2017). In fact, in terms of legitimacy, the different forms of theology and theological inquiry may be less important than the pedagogical principles and procedures governing their deployment. This can be illustrated most effectively with reference to potentially controversial applications of theology and theological inquiry in so-called 'non-confessional' multi-faith RE. Uncritical, monologic and dogmatic theologies, for example, can be encountered and investigated legitimately through critical, dialogic and inquiry-led learning processes. Theology predicated on acceptance of a theistic worldview and referring to the (in)formal attempts of believers in God to organise, communicate, contemplate and/or justify their ideas might be studied legitimately as 'content' through empathetic and critical procedures. At least in theory, with many caveats concerning practical implementation (such as assuring sufficient critical distance is maintained), theological inquiry of the same 'confessional' ilk could even be undertaken by all students, regardless of their personal positionalities. The legitimacy of this would depend on it being one of many different interpretative lenses through which they were being asked (temporarily and experimentally) to investigate subject matter (i.e. dialogic); and if its purpose was epistemological and methodological awareness-raising and evaluation (i.e. critical).

It is through consideration of the three distinct, yet interrelated, concepts of positionality, empathy and critique that we will further illustrate what the inter-relationship between theologies, theological inquiries and RE might look like in practice.

\subsubsection{Positionality}

The application of different forms of theology and theological inquiry in multi-faith RE in schools without a religious affiliation should enable students to be conscious of, and regulate, matters relating to positionality. Drawing upon Bakhtin's concept of 'dialogic', Freathy et al. $(2017,426)$ argue for an RE that 'rejects the monological presentation of a single objective reality from a transcendental perspective, in favour of a plurality of incommensurable beliefs and multitude of contested meanings arising from particular contexts'. Such RE embraces a wide range of voices - including theological voices - a 'polyphony' of 'many unmerged and unsubordinated "sounds, voices, styles, references and assumptions" (Bakhtin, 1992)' (p. 426). Through maintaining a critical awareness of the positioning of both those being studied and of those undertaking the study, argue Freathy et al., RE can engage in a process of continually 'questioning normalised practice and constantly problematising the given' (p. 427). Citing Gadamer, they note how 'Whilst neutrality may be impossible, it is possible to gain knowledge of one's own partiality through critical reflection and reflexivity, and of other people's partiality through genuine dialogue characterised by an attitude of openness and respect (Gadamer, 2004)' (p. 427). Engaging the learner in an active, inquiry-led quest for knowledge and understanding in this way, they argue, enables the critical examination of 'phenomena from multiple, and sometimes competing, theoretical and methodological perspectives (Rogers, 2012, p. 1)’ (p. 428). 
Multi-faith RE of this kind seeks neither to create a neutral space in which the objective study of religion(s) can occur, nor to ally itself to any singular faith tradition or singular disciplinary, interpretative and methodological perspective. Instead, it creates a place holder for perspective including Theological, Religious Studies and other disciplinary perspectives - a dialogic space in which plurality and multiplicity can exist and be subject to reflection and critique. Adapting Gavin Hyman's conception of Theology, we might describe critical, dialogic and inquiry-led RE as 'a place where [religions, worldviews, disciplines, theories and interpretations] can confront and engage with each other on their own terms rather than on the a priori basis of a specious pacifism that turns out to be a covert eradication of difference' (Hyman 2004, 217). This echoes Ernst Conradie's (2008) view of a 'spiral of ongoing interpretation', in which texts are subject to a continuous process of reinvention and reinterpretation by successive readers from their own contextualised perspectives. Here Hans Streib concurs: 'Religious education should follow a hermeneutic of fiction'. It should be

education in perception, in seeing, and in hearing, a school of fictionality and imaginative variation, and a school of responsiveness, remembering, and solidarity. Fictionality means to realize the "difference", to realize the "it-could-be-otherwise" in order to play imaginatively with new worlds. Responsiveness means not only to be aware of the otherness of the other, but, as we can say with Ricoeur, learning to see oneself as another. (Streib 1998, 314)

To undertake theological inquiries in such a way, both teachers and students need to become metacognitive, regulating and monitoring their own thinking as they self-consciously engage with the content, skills and mind-set of theologians, while at the same time subjecting theological inquiries to critical analysis and evaluation. This includes reflecting upon how (non-)theological subject matter both shapes, and is shaped by, the (non-)theistic worldviews of themselves and others. Students can then be encouraged to engage from their own tradition-specific perspective, as well as from the perspective of others, deliberately and temporarily assumed, and examined both independently of, and in relation to, their own worldviews.

\subsubsection{Empathy}

In order to move from perceiving the world from one's own point of view to perceiving it from the perspective of another, multi-faith RE needs to encourage empathetic skills, dispositions and attitudes. Initially, a degree of understanding can be gained from learning substantive, conceptual and theoretical knowledge. Beyond this, by temporarily suspending (dis)belief, one can attempt to look at the world from the perspective of the individual or groups that are being studied, be they authors, artists, historians or faith community members. This requires the inclination and ability to get inside the minds and lives of others: a will and a way are necessary. If one lacks the disposition to see something from another's point of view, then one should not expect to understand their point of view. The in-depth study of beliefs requires both understanding ideas and how they interconnect, and empathising with the particular mind-set of another. Theologies and theological inquiries have the potential to make a profound contribution in these regards, for example, via systematic theology, the history of theistic/theological ideas, textual hermeneutics and exegesis, and so forth.

As it is not possible to suspend disbelief completely, we can also identify where sticking points in comprehension lie - that is, the limits of our ability to understand the worldviews of others. As Thomas Nagel tells us, we can never know what it is like to be a bat: it is impossible to fully comprehend the first-person perspective of another; their subjective consciousness is only available 
to us via our own subjective consciousness - that is, second hand, distorted and inaccurate (Nagel 1974). Such limitations are faced by all students, not just 'non-believers' or 'outsiders'. To an extent, we all stand outside each other's worldviews, even if superficially we might share the same religion and/or denomination, for example. Theologies and theological inquiries can be used to demonstrate the possibilities and limitations of empathy, through an awareness of the existence of a multiplicity of theistic/theological perspectives; the in-depth scrutiny of, and familiarity with, the theological subject matter at hand; and self-knowledge, reflection and reflexivity on the part of the 'theologian(s)'. Ascertaining what we know, what we would like to know, and what we can never know, is a high-level skill, and one that can be fostered through the study of theologies and theological inquiries within multi-faith RE.

\subsubsection{Critique}

The application of different forms of theology and theological inquiry in multi-faith RE also needs to engage students in processes of critique, enabling them to unpack for themselves questions relating to what 'theologies' are, how they function in relation to other aspects of the study of religion(s) and worldview(s), and their relevance for people within the world today. Discussing critical inquiry-led learning in the context of RE more generally, Freathy et al. (2017) use the concept of the 'bricoleur' (a term originally used to refer to crafts-people who create new artefacts from the tools and materials to hand). They identify five main types of 'bricoleur' - interpretive, methodological, theoretical, political and narrative (p. 429, drawing upon Denzin and Lincoln (1999) and others) - to express various intellectual tools that might be adopted by teachers to enable students to expose, analyse and evaluate the assumptions underpinning representations of religion(s) and worldview(s) in RE. To engage fully in the process of such critique, these lenses must be adopted in relation not just to some but to all aspects of theological inquiry: subject matter, curriculum resources, methodologies and methods of study, teacher and student perspectives, and so forth. Perceiving all conceptual, theoretical and/or methodological perspectives as contingent means each can then be acknowledged not as the way to understand subject matter, but rather as a way amongst alternative approaches. This means, for example, that multi-faith RE need not fear the application of so-called 'confessional' theological approaches, assuming theistic faith commitment, so long as they are part of a wider repertoire of approaches, and students are enabled and encouraged to maintain both critical distance and critical proximity when appropriate. In order to do this, students and teachers must be aware of their own positionality, empathetic to alternative viewpoints, conscious of the nature of the lens through which curriculum content is being viewed, and have the critical capacity to stand back from both the subject matter and the interpretative framework to analyse and evaluate them.

Geoff Teece (2008) argues, following John Hick, that religions can be united theoretically by soteriology, with each being seen to provide a different, although broadly equivocal, path to salvation. For Teece, soteriology thus provides a unifying concept around which to orientate the otherwise disparate subject matter of RE, enabling students to see connections between the different aspects of their learning. Similarly, and partly as a practical response to the Making a Difference report (Church of England Archbishops' Council Education Division and National Society, 2014), the recent Understanding Christianity project (Understanding Christianity 2016; Pett et al. 2016; Pett 2017) sought to put theology back on to the curriculum. It identified core theories within the Christian faith (God, creation, fall, people of God, prophet/wisdom, incarnation, gospel, salvation and kingdom of God), and then applied them to the study of that particular religion. All four authors of Chipperton et al. (2016) acted as advisors on the project. In accordance with our proposed application of different 
forms of theology and theological inquiry within the context of critical, dialogic and inquiry-led RE, we would reject both these approaches if either was deployed as the singular interpretative framework underpinning multi-faith RE as a whole, potentially covertly endorsing underlying theories and concepts which students would imbibe without knowing. However a careful reading of both reveals that neither intended that to be the case, for example, Pett and Cooling (2018: 7) state that the eight theological concepts which form the spiral curriculum at the heart of Understanding Christianity 'consciously reflects a perspective in itself, in that these concepts tell a story from creation, through fall, to a salvation offered through Jesus as God incarnate' and that this 'is a way of reading the diverse biblical texts as part of a metanarrative of salvation that is shared by many Christians, but it is certainly not the only way' (our emphasis). Thus, both of these insightful perspectives are capable of being applied legitimately, so long as they are explicit rather than implicit, one amongst many contrasting approaches, and the object themselves of critical scrutiny, with students being encouraged: (i) to recognise where they stand vis-à-vis each perspective (positionality); (ii) to explore the potential explanatory power of each perspective for those who hold to them (empathy); and (iii) to subject them to analysis and evaluation (critique).

Similarly, the recent 'Identifying Principles and Big Ideas for Religious Education' project (Wintersgill 2017) proposed six 'Big Ideas for RE' which could be used to determine the selection and prioritisation of subject content knowledge (including, for example, 'The Big Picture' that religions and non-religious worldviews provide accounts of the nature of reality, and of how and why the world is as it is). However, the 'Big Ideas', like all such theories and generalisations, are grounded in particular ontological, epistemological and methodological assumptions that not all scholars share. As a result, Freathy and John (2018) argue for the creation of additional 'Big Ideas about the study of religion(s) and worldview(s)', as part of a multi-disciplinary, inquiry-led, reflexive approach to learning, which asks where, when, how and by whom are 'Big Ideas' generated, thereby inviting students to engage in explicit consideration of epistemological and methodological issues within the RE curriculum.

The application of different forms of theology and theological inquiry in multi-faith RE in schools without a religious affiliation can contribute to the development of each and every student's individual understandings of religion(s) and worldview(s) by allowing them to encounter, and enter into, a multiplicity of alternative understandings. Thereby they will gain greater awareness of the various ideological and philosophical foundations, and ontological and epistemological assumptions, upon which studies of religion(s) and worldview(s) are predicated. This will make students more critical, reflective and systematic in their thinking, and thus make them better students of religion(s) and worldview(s). There is no necessity to demand that students hold (non-)theistic worldviews as a prerequisite, or as a 'post-requisite': there need be no intention to develop or transform the worldviews of students in any particular pre-determined ways, and the indeterminacy and unfinalizability of personal lessons learned and conclusions reached by students can be safeguarded through free discursive acts in open-ended (trans)formative dialogue (Bakhtin, 1986, in Freathy et al. 2017). At the same time, however, students cannot remove themselves from the equation: there is no guarantee that the acquisition of knowledge and understanding, and broadening of personal horizons, will not be accompanied by other forms of development on the part of students (e.g. spiritual, moral, social and cultural), even if these are not prescribed or intended outcomes. 


\section{Conclusion}

Different forms of theology and theological inquiry can be utilised as legitimate approaches within critical, dialogic and inquiry-led multi-faith RE in schools without a religious affiliation. Both can be applied in ways which are continually aware of, and embrace, the existence of multiple positions and perspectives, including those that are being studied, those of the teacher, those of the students, those embedded in curriculum resources, and so forth. Critical and self-reflexive analysis can be incorporated into the application of theologies and theological inquiries at every turn, approaching the worldviews of others with empathy and an intention to further (self-)understanding, and accepting that any study of faith and beliefs should involve wrestling with complex epistemological and methodological issues. To set up categorical distinctions between the nature and purpose, and contents and methods, of Theology and Religious Studies, and between theology which assumes a theistic faith commitment and theology which does not, creates simplistic binary oppositions: that we all have our own positions and perspectives needs to be revealed and recognised rather than disguised and denied. There need be no intention to promote or require any particular (theistic) faith commitment, but rather an awareness of the importance of positionality, empathy and critique in theological and all other forms of inquiry. Multi-faith RE in schools without a religious affiliation may need, as Hyman puts it, to "eschew both the "inside" positioning of theology and the "outside" positioning of the "old" religious studies in favour of a disposition that is "betwixt and between", a disposition of ambivalence. Both strands, therefore, represent movements to an "intermediate zone", together constituting a deconstruction of the dialectical opposition between a "pure" theology and a “pure" religious studies...' (2004, 215-6). In this liminal space, multi-faith RE can be characterised as a dialogic carnival of disciplinary, interpretative and methodological plurality, through which students are provided with a knowledge and critical awareness of a range of perspectives involved in the study of religion(s) and worldview(s). If there has been a taboo surrounding the implementation of theology and theological inquiry in multi-faith RE, this pedagogical framing has the capacity to break it.

\section{Note}

1. We use 'inquiry' rather than 'enquiry' in the context of 'inquiry-led learning'. Although often used interchangeably, 'enquiry' has connotations of asking for or requesting pre-existing information, while 'inquiry' is often associated with researching or investigating to generate new knowledge (Baumfield and Higgins 2008).

\section{References}

Astley, J. and L. J. Francis. 1996. Christian Theology and Religious Education: Connections and Contradictions. London: SPCK.

Aylward, K. and R. Freathy. 2008. 'Children's conceptions of Jesus.' Journal of Beliefs and Values 29(3): 297-304.

Bakhtin, M. 1986. (Translated from the Russian by V. W. McGee) Speech Genres and Other Late Essays, edited by C. Emerson and M. Holquist. Austin: University of Texas Press.

Bakhtin, M. 1992. The Dialogic Imagination: Four Essays. Austin: University of Texas Press. Bates, D. 1994. 'Christianity, culture and other religions (Part 1): the origins of the study of world religions in English education.' British Journal of Religious Education 17(1): 5-18

Bates, D. 1996. 'Christianity, culture and other religions (Part 2): F H Hilliard, Ninian Smart and the 1988 Education Reform Act.’ British Journal of Religious Education 18(2): 85-102. 
Baumfield, V. and S. Higgins. 2008. 'Child And The Curriculum In The $21^{\text {st }}$ Century: The Relationship Between Enquiry And Inquiry In The Classroom'. Paper presented at the annual meeting of the American Education Research Association, New York, March 24-28.

Bloom, A. 2018. 'The Battle for the Soul of RE.' Times Educational Supplement. 17th March 2018. https://www.tes.com/news/school-news/breaking-news/long-read-battle-soul-

re?amp\&_twitter_impression=true. [Accessed 29.03.18]

Brine, A. 2016a. 'Thinking theologically in RE? Part 1.' RE:ONLINE.

http://www.reonline.org.uk/news/alans-blog-thinking-theologically-in-re-part-1-alan-brine/

April 25, 2016. [Accessed 29.03.18]

Brine, A. 2016b. 'Thinking theologically in RE? Part 2.' RE:ONLINE. http://www.reonline.org.uk/news/alans-blog-thinking-theologically-in-re-part-2-alan-brine/. May 3, 2016. [Accessed 29.03.18]

Brine, A. L. 2017. 'Theology made in dignity: on the precarious role of theology in religious education.' Journal of Beliefs \& Values 39(1): 120-22. DOI: 10.1080/13617672.2017.1360002.

Brine, A. 2018. 'Religious Education and the "theology issue". RE:ONLINE. http://www.reonline.org.uk/news/religious-education-and-the-theology-issue/

[Accessed 23.03.2018]

Burton, T. I. 2013. 'Study Theology, Even If You Don't Believe in God.' The Atlantic. https://www.theatlantic.com/education/archive/2013/10/study-theology-even-if-you-dont-believe-

in-god/280999/. October 30, 2013. [Accessed 29.03.18]

Büttner, G. 2007. 'How theologising with children can work.' British Journal of Religious Education 29(2): 127-139.

Chipperton, J., G. Georgiou, O. Seymour, and K. Wright. 2016. 'Rethinking RE: Religious Literacy, Theological Literacy and Theological Enquiry.'

http://reonlineorg.wpengine.com/wp-content/uploads/2016/02/REThinking-RE-REOnline.pdf

[Accessed 18.05.18]

Church of England Archbishops' Council Education Division and National Society. 2014. Making a

Difference? A Review of Religious Education in Church of England Schools. London: Church of England.

Conradie, E. M. 2008. Angling for Interpretation: A first introduction to biblical, theological and contextual hermeneutics. Stellenbosch: Sun Press.

Cooling, T. 1994. Concept Cracking: Exploring Christian Beliefs in Schools. Stapleford: Association of Christian Teachers.

Copley, C., T. Copley, R. Freathy, S. Lane, and K. Walshe. 2004. On the Side of the Angels, the Third Report of the Biblos Project. Exeter: School of Education and Lifelong Learning, University of Exeter.

Copley, T., R. Freathy and K. Walshe. 2005. Teaching Biblical Narrative: a summary of the main findings of the Biblos Project, 1996-2004. University of Exeter: School of Education and Lifelong Learning.

Copley, T. 2001. 'Children "theologising" in RE: The Joseph story as a case study in three religions and competing cultures.' Education Today 51: 3-7.

Copley, T. 2005. 'Young People, Biblical Narrative and "Theologizing”: A UK Perspective.' Religious Education 100(3): 254-265.

Copley, T. 2008. Teaching Religion: Sixty years of religious education in England and Wales, Exeter: University of Exeter Press. 
Cush, D. 1999. 'The Relationships between Religious Studies, Religious Education and Theology: Big Brother, Little Sister and the Clerical Uncle?' British Journal of Religious Education 21(3): 137146.

D'Costa, G. 2000. The Meeting of Religions and the Trinity. New York: Orbis Books.

Denzin, N. K. and Y. S. Lincoln. (Eds) 1999. The SAGE Handbook of Qualitative Research (3rd edition). Thousand Oaks: Sage Publications.

Doney, J. 2015a. 'How did it become possible? Supranational Ecumenical developments and changes in Religious Education during the 1960s and 1970s.' Nordidactica: Journal of Humanities and Social Science Education 2: 24-46.

Doney, J. 2015b. 'The overlooked ecumenical background to the development of English religious education. In History, Remembrance and Religious Education, edited by S. G. Parker, R. Freathy and L. Francis, 139-166. Oxford: Peter Lang.

Freathy, R. and K. Aylward. 2010. "Everything is in parables": an exploration of pupils' difficulties in understanding Christian beliefs concerning Jesus.' Religious Education 105(1): 86-102.

Freathy, R., J. Doney, G. Freathy, K. Walshe and G. Teece. 2017. 'Pedagogical Bricoleurs and Bricolage Researchers: The case of Religious Education.' British Journal of Educational Studies 65(4): 425-443.

Freathy, R., and H. C. John. (2018). 'Big Ideas, Religious Education and the Study of Religion(s) and Worldview(s).' British Journal of Religious Education.

Freathy, R. J. K. and S. G. Parker. 2015. 'Prospects and problems for Religious Education in England, 1967-1970: curriculum reform in political context.' Journal of Beliefs and Values 36(1): 5-30.

Gadamer, H. G. 2004. Truth and Method. London: Continuum.

Harvard Divinity School. 2018. 'Diversity at HDS'. https://hds.harvard.edu/admissions-aid/diversityat-hds. [Accessed 10.11.18]

Howard, A. 2016. Appendix 2. SACRE Briefing. Torbay: Torbay Council.

Hull, J. 1984. Studies in Religion and Education. Lewes: The Falmer Press.

Hyman, G. L. 2004. 'The Study of Religion and the Return of Theology.' Journal of the American Academy of Religion 72(1): 195-219.

Jackson, R. 1990. 'Religious Studies and Developments in Religious Education in England and Wales.' In Turning Points in Religious Studies, edited by U. King, 102-116. Edinburgh: T\&T Clark. Lealman, B. 1978. 'Seven years with a phenomenological syllabus.' Learning for Living 17(4): 159162.

Lipman, M. 1988. Philosophy goes to School. Philadelphia: Temple University Press.

McGrath, A. E. 2007. Christian Theology: An Introduction. Oxford: Blackwell Publishing.

Marvell, J. 1976. 'Phenomenology and the future of religious education.' Learning for Living 16(1): 4-8.

Moulin, D. 2009. 'A Too Liberal Religious Education? A Thought Experiment for Teachers and Theorists.' British Journal of Religious Education 31(2): 153-65.

Nagel, T. 1974. 'What is it like to be a bat?' Philosophical Review 83: 435-450.

Netto, B. 1989. 'On Removing Theology from Religious Education.' British Journal of Religious Education 11(3): 163-168.

Office for Standards in Education (OFSTED). 2013. Religious Education - Realising the Potential. Manchester: Office for Standards in Education.

Parker, S. G. and R. J. K. Freathy. 2012. 'Ethnic diversity, Christian hegemony and the emergence of multi-faith religious education in the 1970s.' History of Education 41(3): 381-404. 
Pett, S. 2017. "Making a Difference? Developing 'Understanding Christianity." Professional REflection 34(2): 60-63.

Pett, S. and T. Cooling. 2018. 'Understanding Christianity: exploring a hermeneutical pedagogy for teaching Christianity.' British Journal of Religious Education, DOI: 10.1080/01416200.2018.1493268

Pett, S., L. Blaylock, K. Christopher, J. Diamond-Conway, H. Matter, and F. Moss. 2016. Understanding Christianity: Text Impact Connections - The Teacher's Handbook. Birmingham: RE Today.

Quality Assurance Agency. 2014. Subject benchmark statement for Theology and religious studies. Gloucester: The Quality Assurance Agency for Higher Education.

Reed, E. D., R. J. K. Freathy, S. Cornwall, and A. Davis. 2013. 'Narrative theology in Religious Education.’ British Journal of Religious Education 35(3): 297-312.

Roebben, B. 2016. Theology made in dignity: on the precarious role of theology in religious education. Paris: Peeters.

Rogers, M. 2012. 'Contextualizing Theories and Practices of Bricolage Research.' The Qualitative Report 17 (T\&L Art. 7): 1-17.

Schools Council. 1971. Working Paper 36: Religious Education in Secondary Schools. London: Evans Methuen.

Sharpe, E. F. 1975. 'The phenomenology of religion.' Learning for Living 15(1): 4-9.

Schneider, N. 2010. 'Theology for atheists.' The Guardian. Monday $4^{\text {th }}$ January 2010. https://www.theguardian.com/commentisfree/belief/2010/jan/04/religion-atheism [Accessed 10.11.2018]

Schweitzer, F. 2014. 'Adolescents as Theologians: A New Approach in Christian Education and Youth Ministry.' Religious Education 109(2): 184-200.

Smart, N. 1968. Secular Education and the Logic of Religion. London: Faber.

Smart, N. 1973. The Phenomenon of Religion. London: Macmillan.

Smart, N. 1983. Worldviews: Crosscultural Explorations of Human Beliefs. New York: Charles Scribner's Sons.

Smart, N. 1998. 'Methods in My Life', In The Craft of Religious Studies, edited by J. R. Stone, 1835. Basingstoke: Macmillan.

Streib, H. 1998. 'The Religious Educator as Story-Teller: Suggestion from Paul Ricoeur's Work.' Religious Education 93(3): 314-331.

Teece, G. 2008. 'Learning from religions as "skilful means": a contribution to the debate about the identity of religious education.’ British Journal of Religious Education 30(3): 187-198.

The Church of England. 2018. Curriculum Design in Religious Education. https://t.co/IsOPhWbcje. March 15, 2018. [Accessed 29.03.18]

Understanding Christianity. 2016. http://www.understandingchristianity.org.uk/teachers-andschools/ [Accessed 18.05.18]

Walshe, K. S. J. and G. M. Teece. 2013. 'Understanding “understanding” in Religious Education.' British Journal of Religious Education, 35(3): 313-325.

Wintersgill, B. ed. 2017. Big Ideas for Religious Education. Exeter: University of Exeter.

Wright, A. 1993. Religious Education in the Secondary School. Prospects for Religious Literacy. London: David Fulton. 